\title{
INSTITUTE OF GAS TECHNOLOGY
}

\section{MASTER}

\author{
PEAT AS AN ENERGY ALTERNATIVE
}

by

D. V. Punwani

Paper Submitted to

TECHNOLOGY TOMORROW

3424 SOUTH STATE STREET

IIT CENTER

CHICAGD, ILLINOIS 60616 


\section{DISCLAIMER}

This report was prepared as an account of work sponsored by an agency of the United States Government. Neither the United States Government nor any agency Thereof, nor any of their employees, makes any warranty, express or implied, or assumes any legal liability or responsibility for the accuracy, completeness, or usefulness of any information, apparatus, product, or process disclosed, or represents that its use would not infringe privately owned rights. Reference herein to any specific commercial product, process, or service by trade name, trademark, manufacturer, or otherwise does not necessarily constitute or imply its endorsement, recommendation, or favoring by the United States Government or any agency thereof. The views and opinions of authors expressed herein do not necessarily state or reflect those of the United States Government or any agency thereof. 


\section{DISCLAIMER}

Portions of this document may be illegible in electronic image products. Images are produced from the best available original document. 
PEAT AS AN ENERGY ALTERNATIVE

by

D. V. Punwani

Institute of Gas Technology

Chicago, Illinois

\section{INTRODUCTION}

The importance of developing alternative energy sources to augment supplies of fossil fuels is growing all over the world. Coal, oil shale, tar sands, biomass, solar, geothermal, nuclear, and hydroelectric power have received considerable attention as alternative energy sources. One large energy resource, however, has received little attention until recently. That resource is peat. Although peat is used an an energy source in some countries such as Russia, Ireland, and Finland, it is virtually unexploited in many countries including the United States. This paper provides an understanding of peat: its varieties, abundance, and distribution; its value as an energy alternative; its current and future role as an energy alternative; and the environmental and socioeconomic impacts of large-scale peat utilization.

\section{WHAT IS PEAT?}

Peat is a heterogeneous material consisting of partially decomposed plant and vegetable matter and inorganic minerals that have accumulated in a watersaturated environment over thousands of years. The remains of many common plants have been identified in peat: trees, heath shrubs, sedges, mosses, grasses, poundweeds, reeds, cattails, algae, and ferns. Under favorable conditions most of these plants multiply rapidly, and in some places large quantities of dead vegetation accumulate yearly. If this dead matter is exposed to air and aerobic bacteria, decomposition occurs without peat formation. However, when the plant debris is protected from contact with air 
because it is immersed in water, peat is formed. This peat contains a substantial portion of the carbon and hydrogen of the original organic matter. Entrapment of peat by movement of the earth's crust may lead to extremely high pressures and temperatures, and the "coalification" process proceeds to form higher ranks of coal. Although peat is not generally categorized in the ranks of coal, it is considered the first geological step in the formation of coal beds. The sequence starts with growing vegetation and proceeds to peat, lignite, bituminous coal, semianthracite, and anthracite to metaanthracite or graphite. That is why one often describes peat as a "young coal."

The "coalification" process principally involves the removal of oxygen in the form of carbon dioxide and water. As a result, the concentration of combustible material (carbon and hydrogen) increases, and the remaining material has an improved heating value. Because peat is formed in a water-saturated environment, peat as it occurs in nature contains about $90 \%$ water. The major components of peat and other coals that affect the combustion energy are fixed carbon, volatile matter, and oxygen. A comparison of the major components of peat with those of other coals is shown in Figure 1 . The increase in the fixed carbon is accompanied by a reduction in volatile matter and oxygen content and generally with an increase in the' fuel's heating value.

\section{VARIETIES OF PEAT}

To most people, the word peat refers to the material commonly used as a soil conditioner. That, however, is only one of the many kinds of peat. The properties of peat vary depending upon the types of contributing vegetation and the degree of decomposition. The three most common categories are fibric (peat moss), hemic (reed-sedge), and sapric (humus). 
Fibric peats are composed of sphagnum, hypnum, and other mosses. They are the least decomposed of the three types of peat and have the highest fiber content (minimum of $66.7 \%$ sphagnum moss fiber). Fibric peats also have a high water-retention capacity, low bulk density, and low ash content. Because they are the least decomposed form of peat, they have the lowest heating value on a dry and ash-free basis. Fibric peats are most desirable for horticultural use as soil conditioners and least desirable as fuel peats for energy use.

Hemic peats are formed from reeds, sedges, swamp plants, and trees. They have a lower fibcr content and are more decomposed than fibric peats. These peats have a higher heating value and lower water-retention capacity than fibric peats.

Sapric peats are composed of materials that have decomposed beyond botanical recognition. These peats are the oldest and most decomposed. On an ash-free basis the sapric peats have the highest energy content. The ash content of sapric peats varies from as $10 w$ as $2 \%$ to as high as $60 \%$, thus reducing their energy value. Some of the other peat classification systems are shown in Table 1. The American Society for Testing and Materials (ASTM) is attempting to revise the peat definition and classification systems.

\section{PEAT RESOURCES}

Peat is a worldwide resource. A map of world peatlands is shown in Figure 2. About $95 \%$ of the world peat resources are found in Europe, Asia, and North America. Estimates of peatland areas in the countries richest in peats are shown in Table 2. Surveys of peat resources throughout the world. have been limited and vary considerably, mostly because of differences among the 
methods used by various countries for reporting their peat resources. Some countries, other than those listed in Table 1, might have deposits that are not large enough to substantially add to the total world resources, but are nonetheless - significant to those countries and can still be considered valuable as energy resources. These countries include New Zealand, Argentina, Uruguay, Brazil, Paraguay, Iceland, Sri Lanka, and Burundi. Tropical areas of Africa, Indonesia, and Malaysia might also have large peat deposits.

The energy contained in the 52.6 million acres of U.S. peat resources is estimated to total about 1440 quads $\left(10^{15}\right.$ Btu's): the equivalent of about 240 billion barrels of crude oil. These estimates are based on a certain set of assumptions. Work is now being done to obtain better estimates of the peat resources in the United States. Based on the same assumptions used for estimating energy contained in the U.S. peat resources, the world peat resources are estimated to exceed the energy equivalent of 1800 billion barrels of oil.

The total estimated peat resources compare favorably with proved and currently recoverable reserves of other fossil fuels; such as petroleum, natural gas, and Western oil shale, as shown in Figure 3. Even though only a fraction of the total estimated peat resources will be categorized as proved and currently recoverable reserves after detailed surveys of peat resources have been completed, it is still a significant fossil fuel resource.

Peat is found in al1 50 states; however, more than $90 \%$ of the peat resources are located in parts of Alaska (outside of the permafrost regions), Minnesota, Michigan, Florida, Wisconsin, Louisiana, North Carolina, Maine, and New York. (See Table 3.) Many of the peat-rich states have no significant resources of other fossil fuels (Figure 4). The same is also true for many countries such as Finland, Sweden, and Iceland, for which peat is the only 
fossil fuel resource. This circumstance enhances the importance of developing peat resources for those areas.

\section{IS PEAT ECONOMICALLY COMPETITIVE?}

Can peat be economically competitive with other energy alternatives even though it has a low heating value and low bulk density and may contain, in its natural state, about $90 \%$ water? The fact that peat is being commercially used in Russia, Ireland, and Finland attests to the fact that it can be economically competitive. Russia has not just a few peat-fired electricity generation plants, but as many as 76 , some of which have generating capacities exceeding 700 megawatts. Even though the absolute economics of peat-fired power-generation plants in Russia is not known, it is assumed that using peat in these plants must be more economically favorable than bringing coal, oil, or gas into the areas of peat deposits. Remember that Russia is a net exporter of oil, gas, and coal; it is not experiencing a scarcity of these fuels that might otherwise force the use of peat even if it were not economically favorable.

In Ireland, peat has been used for electric power generation since 1950. About one-third of the total thermally generated electric power now is produced in peat-fired plants.

Finland is by far the country most actively committed to increasing the commercial use of peat. Between 1975 and 1978, it increased its use of peat for energy 10-fold. Eleven peat-fired boilers are in operation in Finland. Peat-fired boilers in Finland are competitive with oil-fired boilers. Because peat is a domestically available energy resource, it is preferred over oil, which must be imported. 
Because peat contains about $90 \%$ water, it is impossible to burn. The heat required to simply evaporate the water is greater than the heat of combustion of the peat. However, if the moisture content is reduced from $90 \%$ to $70 \%$, the amount of water is reduced to about one-fourth of the original quantity. Thus, the heat needed to evaporate the water is on $1 y 27 \%$ of the available heat. If the peat moisture content can be reduced to $50 \%$ before combustion, the amount of heat required to evaporate the remaining water is on1y $12 \%$ of the available heat. Fortunately, the water contained in peat can be reduced to $50 \%$ molsture by exposing the wet peat to sun and air for a few days. Peat commercially harvested in Russia, Finland, and Iceland for electricity generation plants contains $35 \%$ to $55 \%$ moisture. Bechtel Power Corporation recently conducted a study for First Colony Farms on large-scale peat harvesting in the United States to support a 600-megawatt electricity generation plant. Results show that it is technically and economically feasible to produce peat containing $35 \%$ to $50 \%$ moisture using the air drying technique.

Peat has advantages over other coals that sometimes more than compensate for the disadvantages of being a lower grade fuel:

- Peat deposits are generally located in areas that have virtually no other significant fossil fuel resource.

- Peat is not a physically hard material like coal and oil shale.

Peat deposits occur near the surface with little or no overburden, and the deposits are generally no deeper than 25 feet.

- Peat is generally low in sulfur content: only about $0.2 \%$ compared with as much as $4 \%$ in some bituminous coals.

- Peat can be lower than coal in ash content.

- Peat has a high hydrogen-to-carbon ratio, (even after accounting for the hydrogen that will react with the oxygen in the peat). 
The recent peat gasification work conducted at the Institute of Gas Technology (IGT) under the sponsorship of the U. S. Department of Energy (DOE) and Minnesota Gas Company (Minnegasco) shows that compared with coal -

- Peat has a higher tendency to make hydrocarbon gases (natura1 gas components) during the initial stage of gasification (when most of the volatile matter in peat reacts with hydrogen) as shown in Figure 5.

- The carbon remaining in the peat after the initial gasification stage is significantly more reactive than the carbon left after initial gasification of lignite and other coals. (Figure 6.)

- Peat has higher volatile matter and lower fixed carbon content.

- Peat gasification produces a higher yield of hydrocarbon gases at relative low hydrogen partial pressures.

- During the initial gasification stage (in the presence of hydrogen) the yield of gasoline blending feedstock and fuel oil is significantly higher (Figure 7).

- Relative distribution between gas and oil yield can be attained over a wider range.

All of the above factors contribute to more favorable production efficiency and economics. Recent estimates show that conversion of peat to high-Btu gas (substitute for natural gas) is competitive with conversion of other fossil fuels to synthetic high-Btu gas. Therefore, peat can be an economical energy alternative depending upon regional energy needs, location of peat deposits, cost of other energy alternatives, and scale of operation. ENVIRONMENTAL IMPACTS

As with the development of any large-scale alternative energy recourcc, the environmental impacts of large-scale utilization of peat must also be evaluated. Environmental systems analyses indicate that peat harvesting techniques, local hydrology and water quality, and reclaimed land-use options 
are interrelated and that a comprehensive plan embracing all three of these areas must be formulated. The harvesting plan must include control of surface and groundwater flows throughout the project area:

Peatlands are wetlands, and, because some unique biological species might exist in them, it might be desirable to preserve and protect those wetlands. Work must be done to identify those areas.

une of the betefits of a large-acale peat utilizatinn program is that it creates productive land. Virtually none of the peatlands in the United States are in productive use. Harvested peatlands can be used for crop production and as wildlife habitats, lakes, ponds, and energy farms. In Europe and Canada, harvested peatlands have been successfully used for agricultural purposes. In the United States, recent experiments by First Colony Farms in North Carolina on the reclamation of harvested peatlands for agricultural purposes have been very successful.

\section{THE FUTURE PROSPECTS}

The U.S. Department of Energy, the Gas Research Institute, the Minnesota Gas Company, the First Colony Farms, and the state energy agencies all recognize the potential of peat as an alternative energy source and are funding work in the areas of improved resource estimation, improved dewatering and harvesting technology, gasification prucess development, and environmental and socioeconomic impact assessment. Governments of Canada, Finland, Sweden, Iceland, Burundi, and Sri Lanka are also exploring the potential of utilizing their peat resources for energy. The overall objective of the current programs is " to develop technology for using peat in an economical and environmentally acceptable manner. 